\title{
Contraception: present and future
}

\author{
Nancy J. Alexander
}

\begin{abstract}
Abstrak
Sampai saat ini belum ada satupun kontrasepsi yang ideal. Kontrasepsi yang paling banyak dipakai saat ini adalah kontrasepsi hormonal berisi progestin saja atau kombinasi dengan estrogen. Dapat berupa pil kombinasi, pil mini, suntikan, implan, cincin vagina atau AKDR. Antiprogestin merupakan penemuan yang penting dalam pengaturan fertilitas. AKDR tembaga dapat dipakai sampai 10 tahun. Kontrasepsi vaksin merupakan salah satu alternatif. Pengembangan kontrasepsi pria banyak kendalanya. Kontrasepsi barrier dalam era AIDS/HIV makin penting, karena bersifat dwi-fungsi. Untuk mendapatkan kontrasepsi baru diperlukan waktu, upaya dan biaya.
\end{abstract}

\begin{abstract}
Until now there is no any ideal contraceptive. The ideal contraceptive would be long-acting, highly effect, safe, easily reversible and have few or no side effects. The most widely used contraceptive are hormonal, either progestin only or in combination with estrogen. Followed by sterilization and IUD. In addition to the oral route, hormone can be delivered in many ways. They can be delivered by implants or by injection and soon will be available as a ring that can be placed in the vagina for three weeks and removed for one. The development of the first antiprogestins represents an important milestone in fertility regulation. The emergence of the Copper-bearing IUD with a 10-year life span, has placed a new dimension on the importance of this contraceptive approach. There are extensive efforts to develop vaccines based on antigens unique to the spermatozoa and ova. Since men produce at least 1000 sperm per minute, preventing either their production or making them incapable of fertilization has proved to be a difficult undertaking. As the incidence of sexual transmitted diseases (STD) continues to climb, it is increasingly important to combine contraception with effective barriers against STD. New methods will take time, initiative and a concerted effort.
\end{abstract}

Keywords: Contraception, present, future.

\section{HORMONAL CONTRACEPTION FOR WOMEN}

Exccept possibly for sterilization, administration of hormones (i.e., synthetic estrogen-progestin combinations or progestins alone) is the most widely used contraceptive approach. This method has proven to be safe and very effective for the vast majority of women. Furthermore, the use of oral contraceptives (OC) has beneficial effects; $O C$ reduces the rate of both ovarian and endometrial cancer. In fact, in many countries, OC are considered to be so safe that they are sold without a prescription.

Hormonal contraceptives prevent ovulation by inhibition of GnRH from the hypothalamus and this lack suppresses FSH and LH secretion. In addition, both estrogen and progestin have direct effects on the reproductive tract by altering motility of the fallopian tube and interrupting endometrial development.

Senior Scientific Advisor

Organon Inc, West Orange, NI 07062, USA
Orally active contraceptives contain either a combination of estrogen and progestin or a progestin alone. Progestins alone are effective while the estrrogen regulates menstrual bleeding and may increase contraceptive effectiveness. Over the years. changes in the chemical composition of the various brands have been almost exclusively changes of the progestational compound of the pill. From norethindrone and norethynodrel, there has been a movement to norgestrel and desogestrel, gestodene and norgestimate. The progestogenic potency of compounds in current use are: levonorgestrel $>$ norgestre $1>$ norgestimate, desogestrel and gestodene $>$ norethindrone. Norgestrel is considered to be the most androgenic progestin and norgestimate, esogestrel and gestodene have less androgenic side effects then the other derivatives of 19-nortestosterone.

Attempts to develop formulations that more closely mimic the ovarian cycle resulted sequential formulations. Triphasics evolved next. Whether these products present a true pharmacologic innovation is difficult to say, for we have no information on whether they offer any additional safety potential over mono- 
phasics. Concerns with the safety of estrogenic component have led to the development of progestin-only pills, containing either norethindrone or norgestrel, but they have never become a dominant force due to the tendency for the users to experience increased spotting and bleeding.

In addition to the ora1 route, hormones can be delivered in many ways. They can be delivered by implants or by injection and soon will be available as a ring that can be placed in the vagina for three weeks and removed for one. Implants and injections have been embraced by some users because they are effective for a considerable time period. Since they are not taken daily, compliance failures are less common. However, an extended duration of action can also be a disadvantage when there is a desire to restore reproductive function; patient must either wait for the effect to disappear or have the implant removed. Monthly injectables combining a long-acting progestin with a shorter-acting estrogen are being introduced in many countries. Their chief advantage is regularized withdrawal bleeding. These products are popular in some countries where service delivery of the product to the client is well established.

The progestin implant, Norplant, is composed of six implants the size of wooden matches with an efficacy period of 5 years. Newer products including Implanon have proved to be very effective and much easier to insert and remove. Considerable effort has been devoted to developing a biodegradable implant that would permit easy remove for a period of tirne after implantation if desired and would subsequently degrade so that no removal would be required.

\section{ANTIPROGESTINS}

The development of the first antiprogestins represents an important milestone in fertility regulation. The combination of an antiprogestin, mifepristone, together with a prostaglandin, has become accepted as an effective and safe medical termination of early pregnancy and the drug is registered in several European countries as well as China. Plans have been made to have it available in the USA in 1999. The marketed dose of mifepristone is $600 \mathrm{mg}$. A WHOsponsored clinical trial clearly demonstrated no loss of efficacy at $200 \mathrm{mg}$ when given in combination with a prostaglandin. While it is a sound principle in pharmacology to use as low a dose as possible, there is some constraint to do so with mifepristone. The hesitation is due to the fact that there is no information on abortifacient efficacy of the $200 \mathrm{mg}$ dose given without the prostaglandin and it is not likely that such studies will be conducted for ethical reasons.

The utility of mifepristone when administered in postcoital emergency mode also has be demonstrated. When give alone at $600 \mathrm{mg}$, the drug prevented pregnancy with many fewer side effects than did the Yuzpe regime.

The availability of antiprogestins has stimulated the imagination of the research community to explore any and all contraceptive potentials of these drugs. The literature is replete with publications detailing administration of antiprogestins during various stage of the menstrual cycle. Blockage of ovulation has been established by either daily administration or by the administration of larger doses at weekly intervals. Since ovulation blockage leads to cycle irregularity, substitution therapy in order to improve cyclicity will be required.

An asynchronous endometrium develops as the result of small $1 \mathrm{mg}$ doses of mifepristone. However, whether such an endometrium will permit the blastocyst to implantation is not yet clear. Histological evaluation of endometrial biopsies suggest asynchrony between ovarian and endometrial cycles that ranges from one to six days. Mid-luteal phase administrations have been suggested as a contraceptive approach. However, since that depends on precise timing of ovulation, it may not practical under routine conditions. Suggestions to use antiprogestins for menses induction are likewise difficult since, again, the precise timing of cycle events is difficult if not impossible. In addition, induction of menses in some cases will result in very early abortions making acceptability more difficult.

\section{INTRAUTERINE DEVICES}

The emergence of the Copper-bearing IUD with a 10year life span, has placed a new dimension on the importance of this contraceptive approach. IUDs with an effective life beyond two years are highly efficacious and exceeding cost effective. Development of the levonorgestrel IUD represents a significant advancement not only because the device is highly effective, but also because the concept of an intrauterine drug delivery system offers the potential of introducing other drugs, possibly antiprogestins and non-hormonal anticonceptional agents into the uterine environment. These agents could block fertilization or prevent implantation without interfering with 
normal menstrual cyclicity. The levonorgestrel IUD is also being used in conjunction with systemic estrogen as part of hormone replacement in postmenopausal women. Thin device is not yet available in the U.S.

\section{IMMUNOCONTRACEPTION}

The success of vaccines in controlling infections has been the basis for attempting to utilize an immune response in fertility regulation. Antigens critical for fertilization are being defined but there are many steps that remain. Animal and clinical studies suggest that a major problem may be the for non-uniformity of rosponse both in terms of time and antibody titers.

Clinical evaluation of vaccines is most advanced with the irnmunocontraceptive against $\beta$-hCG coupled to ovine $\alpha \mathrm{LH}$. During some 750 cycles of exposure only one pregnancy was observed. However, this information must be interpreted with caution since only women in whom the antibody titer reached $50 \mathrm{ng} / \mathrm{ml}$ were admitted into the efficacy phase. Some $20 \%$ of women did not develop such titers and a number of pregnancies took place among them. Whether development of delivery systems and other vaccine vectors will improve the response remains to be seen.

In addition to the clinical experience with the antihCG, two other possibilities have reached preliminary stages of clinical testing, both for the regulation of male fertility. One vaccine is based on production of antibodies to FSH. Animai studies indicate that males immunized against FSH become infertile. A phase I clinical study has been completed in India but the study was to assess safety rather than efficacy. The attractiveness of the anti-FSH vaccine is that it would not require androgen substitution therapy. Recent studies of knockout mice and another genetic study in Finland suggest that lack of the receptor of FSH may not result in infertility in males. Redundant systems may be a factor here. Such studies reduce enthusiasm for an FSH vaccine. Another immunocontraceptive is based on GnRH. Antibodies to GnRH results in "immunological" hypophysectomy but this approach will require androgen substitution therapy.

There are extensive efforts to develop vaccines based on antigens unique to the spermatozoa and ova. The studies have included a number of efforts involving non-human primates and plans for a phase I study are underway for the sperm antigen, LDH-C.

\section{MALE CONTRACEPTION}

There has been great interest by $c$ researchers in developing a male systemic contraceptive agent. Since men produce at least 1000 sperm per minute, preventing either their production or making them incapable of fertilization has proved to be a difficult undertaking. Approaches to male fertility regulation can be placed in two broad categories: 1) indirect efrects via suppression of gonadotropins and 2) direct effects on the testis.

\section{GnRH Antagonists}

GnRH action can be interrupted by antagonists. The advent of $\mathrm{GnRH}$ antagonists brought hope that these drugs might be a more effective method of male contraception. However current antagonists suffer from toxicity at the infection site and are not sufficiently potent to be considered as practical male contraceptive agents. Pharmaceutical companies have recognized the problems inherent in pursuing peptides, in general, as drugs. These problems include difficulties in formulation and very poor oral activity in addition to the high cost of the peptides themselves. The development of non-peptide analogs has become a consideration. One general approach has been to screen libraries of compounds to obtain non-peptide leads and then to design more potent non-peptides with the structural information gained from these leads. Another approach has been to design non-peptides with information gained from previous studies on structure-activity relationships and the conformational properties of the peptide analogs. Additionally, drug delivery systems must be devised that obviate the need for frequent administration.

FSH and luteinizing hormone, LH, stimulate the testis to produce testosterone which leads to sperm production. Some men who are hypogonadotrophic may produce sperm when administered either LH or FSH but both hormones are needed for normal sperm densities. Androgen causes a negative feedback upon both the pituitary and hypothalamus, thus suppressing gonadotropin secretion. High androgen levels have systemic and potential behavioral effects, and the need for frequent administration is a distinct drawback. A crucial goal is to develop male sex steroids with oral or long-acting parenteral androgenic actity.

\section{Chemicals affecting the testis}

Accidental exposure of workers to a variety of compounds has resulted in infertility however such com- 
pounds are much too toxic to be seriously considered for practical use. The compound with the most extensive clinical exposure has been gossypol. However there are toxicological manifestations that preclude its acceptability for widespread male contraception. Attempts to modify the molecule via the synthesis of numerous analogs have failed.

Many chemicals can produce testicular damage because many are toxic to rapidly dividing cells. Compounds that affect only the latter stages of spermatogenesis seem to have more potential. Such a compound should have no effect on spermatogonia and would have a relatively rapid onset of infertility and return of fertility. Spermatogonia are the cells that first divide, forming spermatocytes and subsequently, spermatid. Since meiosis is unique to spermatocytes, arresting their development would be a good contraceptive approach. One problem has been the difficulty in delivering drugs specifically to the seminiferous tubules of the testis.

When the spermatozoa leave the testis, they are not mature but undergo changes in the epididymis. Drugs that target the epididymis may be an effective method to prevent sperm maturation without haiting sperm production. In vitro fertilization studies have provided considerable information on sperm maturation after ejaculation. As sperm mature, cholesterol leaves the membrane making it more fluid. Compounds preventing cholesterol from exiting the sperm membrane could be contraceptive. Support for this hypothesis comes from the finding that men with elevated blood cholesterol concentrations tend to experience fertility problems. In fact, cholesterol-transfer proteins have been identified in the epididymal fluid. Exposure of spermatozoa to progesterone results in an influx of calcium that is necessary for fertilization. Stopping this influx with a calcium channel blocker used to reduce high blood pressure, interferes with feritilization. If a similar drug can cause infertility without serious side effects, this could be an important new approach to contraception.

\section{Testosterone administration}

Recent studies have demonstrated that testosterone enanthate is an effective contraceptives. WHO-supported studies have demonstrated that it causes the induction of azoospermia. However, the weekly injections and the supraphysiologic injections work against its current formulation. A three-month injectable, mostly likely in combination with a progestin, is an effort by a major pharmaceutical company.

\section{BARRIER CONTRACEPTION}

As the incidence of sexually transmitted diseases (STD) continues to climb, it is increasingly important to combine contraception with effective barriers against STD. Barrier contraception can be either physical (male or female condoms, diaphragms) or chemical (spermicides, microbicides). Although animal bladders and silk were used long ago, the advent of latex allowed uniform products to be made. Many couples have unprotected sex even though life-threatening STD or pregnancy may result. Contemporary condoms are derided by some because of their reputation for reducing sexual pleasure. Just recently, the first polyurethane condom has been marketed. Additional new condoms made of polyurethane and other copolymers will soon reach the market. These non-latex strong, thin films enhance heat and tactile sensation. They should be better barriers to infectious agents, show greater resistance to breakage, to degradation by heat, light, ozone, and non-water-based lubricants, and be non-allergenic.

New caps and devices for women such as Lea's Shield and Femcap are being tested. Effective use of barriers are important in reducing pregnancy and possibly STDs. Although modern spermicides have been available since the 1950 s, new agents and formulations are needed that coat the vaginal epithelium, are long-lasting, and do not disrupt the vaginal flora. Vaginal contraceptive that inactive human immunodeficiency virus (HIV) would be a potent tool to reduce the heterosexual transmission of this deadly disease. The development of female-controlled methods of barrier contraception to protect against pregnancy as well as infectious diseases, including HIV, is critically needed.

\section{FEMALE STERILIZATION}

Sterilization is the most widely used method of contraception in the United States with about 600,000 to 700,000 female sterilizations yearly. Recently, the U.S. Collaborative Review of Sterilization published the results of a large prospective study. A notable finding was that the risk of pregnancy after tubal sterilization is higher than has been generally believed. Over a period of ten years, the cumulative failure rate was 18.5 failures per 1,000 sterilization. The risk varied by timing and type of procedure as well as the aging of the woman being sterilized. The highest failure rate was found with interval partial salpingectomy $(\mathrm{PR}=3.9: 95 \% \mathrm{Cl}, 1.4-10.6)$ with spring clip application next and in decreasing order of risk, bipolar co- 
agulation, silicone band application and unipolar coagulation.

Many pregnancies that occur after sterilization are ectopic; in the CREST study $33 \%$ of the failures were ectopic and $50 \%$ of the bipolar coagulation failures were ectopic.

\section{NEW CONTRACEPTIVES}

The ideal contraceptive would be long-acting, high effect, safe, easily reversible and have few or no side effects. In addition, the contraceptive should not associated with coitus, require no continuing supplies, reduce the spread of STDs, and have a low cost. The time required to develop new contraceptive technologies is usually 10 to 20 years, Obviously the contraceptive methods that are now emerging were initiated years ago. New methods will take time, initiate and a concerted effort. This is a big order and no one contraceptive may be able to meet these criteria. 